Original Research Paper

\title{
Oxidative Stress and Reproductive Damage Induced by Lead Acetate in Female Guinea Pig (Cavia porcellus): Curative Effects of Hydroethanolic Extract of Spirulina platensis
}

\author{
${ }^{1}$ Deutcheu Nienga Sorelle, ${ }^{1}$ Ngoula Ferdinand, ${ }^{2}$ Manfo Tsague Faustin Pascal, \\ ${ }^{3}$ Ngouateu Kenfack Omer Bebe, ${ }^{1}$ Mabou Nguemo Jasmine Laura, \\ ${ }^{1}$ Vemo Bertin, ${ }^{1}$ Ngoumtsop Victor Herman and ${ }^{1}$ Tchoumboue Joseph \\ ${ }^{1}$ Laboratory of Animal Physiology and Heath, Department of Animal Science, \\ Faculty of Agronomy and Agricultural Sciences, University of Dschang, Cameroon \\ ${ }^{2}$ Department of Biochemistry and Molecular Biology, Faculty of Science, University of Buea, Cameroon \\ ${ }^{3}$ Department of Animal Biology and Physiology, Faculty of Sciences, University of Yaoundé, Cameroon
}

\author{
Article history \\ Received: 19-01-2019 \\ Revised: $16-03-2019$ \\ Accepted: 08-04-2019 \\ Corresponding Author: \\ Ngoula Ferdinand \\ Laboratory of Animal \\ Physiology and Heath, \\ Department of Animal Science, \\ Faculty of Agronomy and \\ Agricultural Sciences, \\ University of Dschang, \\ Cameroon \\ Email: fngoula@yahoo.fr
}

\begin{abstract}
This study was aimed at evaluating the curative effects of Hydroethanolic Extract Of Spirulina platensis (HESP) on the reproductive function of female Guinea pig exposed to oxidative stress. Sixty females, 3-4 months old, weighing 300-400 g were divided into six groups (10 animals/group). The neutral control received distilled water, the negative control was treated with lead acetate at a dose $12 \mathrm{mg} / \mathrm{kg} . \mathrm{b} . \mathrm{w}$ while the positive control was given $12 \mathrm{mg}$ of lead acetate $/ \mathrm{kg}$ b.w and $100 \mathrm{mg}$ of vitamin C. Groups 4, 5 and 6 were treated with lead acetate at a dose of $12 \mathrm{mg} / \mathrm{kg}$ b.w for the first 30 days and then received from the $31^{\text {st }}$ day to the $90^{\text {th }}$ day HESP at doses of 50,100 and $200 \mathrm{mg} / \mathrm{kg}$.b.w respectively once daily. Results revealed that lead caused prominent toxic effects on fertility, deterioration of sex organs as well as a disruption of serum levels of Luteinizing Hormone (LH), Follicle Stimulating Hormone (FSH) and progesterone. Lead acetate markedly increased tissues oxidative-stress marker (malondiadehyde), whereas it reduces the activities of antioxidant-enzymes, Superoxide Dismutase (SOD), total peroxidase and catalase. These changes were also accompanied by a significant $(p<0.05)$ decrease of body weight gain. However treatment with HESP ameliorated lead acetate-induced anomalies by significantly $(p<0.05)$ increasing the body weight gain, organ weights and feed intake. Also HESP let to a significant $(p<0.05)$ improvement of fertility indices, a significant $(p<0.05)$ increase in serum LH, FSH, progesterone hormones and an increase in antioxidant enzymes. Curative treatment brought about histological tissues protection and a significant $(\mathrm{p}<0.05)$ decrease of toxicity biomarkers (AST, ALT, creatinine and urea) and Malondiadehyde (MDA). In conclusion, lead acetate induced reproductive stress and administration of HESP can mitigate these adverse effects due to its antioxidant properties.
\end{abstract}

Keywords: Curative Effects, Lead Acetate, Oxidative Sress, Reproduction, Spirulina platensis

\section{Introduction}

Lead is one of the environmental pollutants that causes cancer (Flora et al., 2012; Patrick, 2006) imperiling human and animal health (Yildirim et al., 2011). It is used in different industrial processes which increase its presence in the environment (Flora et al., 2012). Also, lead exposure is associated with oxidative stress which leads to reproductive toxicity in both animal and human populations (Carocci et al., 2016; Dorea and Donangelo, 2006; Flora et al., 2012). Soheir (2015) mentioned that lead induced important damages on reproductive
Science

Publications 
functions. Additionally, Madiha et al. (2008) reported that lead induced biochemical and histological disruptions in many organs such as kidney, ovary, liver and endocrine organs due to the increased reactive oxygen species (ROS). Oxidative stress results from an imbalance in the body's oxidants and antioxidants in favor of the first and is known to induce cellular damage (Halliwell, 2007). Under normal circumstances, the body is endowed with effective antioxidant systems, maintaining the antioxidant/pro-oxidant balance. However, in extreme oxidative power, the body's antioxidant machineries are overwhelmed and necessitate exogenous antioxidants (Saxena and Garg, 2010).

In Africa, especially south of the Sahara, the use of plant extracts for the treatment and management of diseases has been in existence since ancient times. A larger number of these tropical plants and their extracts have shown beneficial therapeutic effects such as enhancing fertility and contraceptive compounds, antioxidant, anti-inflammatory, anti-cancer, antimicrobial and aphrodisiac (Raji et al., 2006).

Spirulina platensis is a blue green algae (Mycobacterium) belonging to the family Oscillatoriaceae (Cruchot, 2008). Spirulina is unique among blue-green algae because it has long history of safe use (Hayashi et al., 1996; Mazo et al., 2004). In central Africa, it is used as a primary food source and is currently grown at large scale in many countries for commercial purpose as a nutritional supplement for its high proteins, vitamins and mineral contents (Cruchot, 2008).

Spirulina platensis is a rich source of provitamin A or beta carotene and Superoxide Dismutase (SOD) enzyme. These antioxidants are very effective for prevention of various harmful effects of heavy metals and chemicals (Qureshi et al., 1996). Spirulina is considered as a valuable additional food source of macro and micro nutrients including amino acids, chlorophyll, gammalinoleic acid, carotenoids, Vitamins A, B1, B2, C, E and trace elements such as iron, iodine, selenium and zinc (Mazo et al., 2004). Spirulina platensis possess potent antiviral (Hayashi et al., 1996), antioxidant (Dartsch, 2008; Ramadan et al., 2008), anticancer (Qureshi et al., 1996) antihyperlipidemic, probiotic, antidiabetic, antiobesity effect (Iwata and Inayama, 1987; Cruchot, 2008) and strengthens immune system (Liu et al., 1991; Estrada et al., 2001). These properties were largely related to Spirulina's phycobili protein (Dartsch, 2008) and phycocyanin (Estrada et al., 2001; Wu et al., 2005). Spirulina is gaining more attention from medical scientists as a nutraceutical and pharmaceutical substances (Khan et al., 2005). Thus, spirulina can be used both in nutritional as well as therapeutic strategies (Qureshi et al., 1996) and it may inhibit lipid peroxidation as it is a cocktail of antioxidants (Ramadan et al., 2008).

Therefore, the present study was undertaken to investigate the reproductive toxicity of lead acetate and to evaluate the curative potential of Spirulina platensis against lead acetate induced oxidative reproductive stress.

\section{Materials and Methods}

\section{Animals}

Sixty (60) female cavies (Cavia porcellus) (4 months old, with a mean body weight of $350 \pm 5.3 \mathrm{~g}$ ) were obtained from the Teaching and Research Farm of the University of Dschang. Males were used only as sires and were not treated. Throughout the trial (90 days), males and females were fed with experimental ration.

\section{Housing, Feeding and Prophylactic Measures}

These animals were identified using numbered ring attached on the ear and housed in clean room previously disinfected with CRESYL $®$. The animals were managed intensively, housed in identical cages measuring 100 $\mathrm{cm} \times 80 \mathrm{~cm} \times 60 \mathrm{~cm}$ (length, width and height) and maintained on the normal diets as shown in Table 1 . The cages had mesh openings to provide ventilation.

\section{Preparation of Plant Extract}

Spirulina platensis was collected from Lake Chad in June 2017. The plant material was shade-dried, ground to obtain fine powder which was macerated in ethanol $\left(70^{\circ}\right)$ for $72 \mathrm{~h}$. After filtration, the filtrate was concentrated under vacuum to remove ethanol and further dried using a freeze dryer to obtain fine powder.

Table 1: Composition and chemical characteristics of the feed

\begin{tabular}{lr}
\hline Ingredients & Quantities (\%) \\
\hline Maize & 26.50 \\
Wheat bran & 3.00 \\
Kernel cake & 12.00 \\
Soy beans cake & 5.00 \\
Cotton cake & 6.00 \\
Premix 5\% & 5.00 \\
Fish meal & 2.00 \\
Palm oil & 2.00 \\
Sea shells & 2.00 \\
Salt & 0.50 \\
Rice bran & 15.00 \\
Total (kg) & 100.00 \\
Chemical characteristics (calculated) & \\
Metabolisable energy (kcal/kg) & 2600.00 \\
Crude proteins (\% DM) & 19.00 \\
Crude cellulose (\% DM) & 14.18 \\
Calcium (\% DM) & 1.26 \\
Phosphorus (\% DM) & 0.55 \\
Sodium (\% DM) & 0.27 \\
Lysine (\% DM) & 1.01 \\
Methionine (\% DM) & 0.40 \\
\hline
\end{tabular}

*Premix: Mineral Nitrogen Mineral Complex: DM: dried matter 


\section{Chemicals}

Lead acetate was obtained from commercial sources (Trust Chemical Laboratories, United Kingdom; P.NO AIPL/20140112UN/2915.2990). Vitamin C was also obtained from commercial sources; (Shalina, Nariman point, Mumbai, India. A/Em/At: Plot No. E-2, M.I.D.C. Jejuri; Tal: Purandar. Dist : Pune, Maharashtra, India).

\section{Experimental Design}

Female Guinea pigs were divided into six groups of 10 animals each as follow:

- Group I: neutral control received distilled water for 90 days.

- Groups II: negative control received $12 \mathrm{mg} / \mathrm{kg} / \mathrm{b} . \mathrm{w}$ of lead acetate diluted in distilled water for 90 days.

- Group III: positive control treated for the first 30 days with lead acetate $(12 \mathrm{mg} / \mathrm{kg}$ b.w.) and then received $100 \mathrm{mg} / \mathrm{kg} / \mathrm{bw}$ of vitamin C from the $31^{\text {st }}$ day to the $90^{\text {th }}$ day.

- Group IV: females treated for the first 30 days with lead acetate $(12 \mathrm{mg} / \mathrm{kg} . \mathrm{b} . \mathrm{w})$ and then treated with 50 $\mathrm{mg} / \mathrm{kg} / \mathrm{bw}$ of HESP from the $31^{\text {st }}$ day to the $90^{\text {th }}$ day.

- Group V: females treated for the first 30 days with lead acetate $(12 \mathrm{mg} / \mathrm{kg} . \mathrm{b} . \mathrm{w})$ and then received 100 $\mathrm{mg} / \mathrm{kg} / \mathrm{b} . \mathrm{w}$ of HESP from the $31^{\text {st }}$ day to the $90^{\text {th }}$ day.

- Group VI: females administered with lead acetate for the first 30 days (12 mg/kg.b.w) and then received $200 \mathrm{mg} / \mathrm{kg} / \mathrm{bw}$ of HESP from the $31^{\text {st }}$ day to the $90^{\text {th }}$ day.

All the females were treated for 90 days including 60 days of pregnancy. After 30 days, mating was done by placing 2 non-treated males into cages containing five treated females. At the end of the trial, female animals were sacrificed under ether anesthesia for blood collection. The blood was collected from the ventral aorta and stored at room temperature. Serum was collected 12 hours later for the estimation of reproductive hormones levels, serum hepatic enzymes (ALT, AST), oxidative stress and renal markers (creatinine and urea). Fetuses and organs were also collected and weighed. After the sacrifice, the remains of animals were carbonized into sanitary pits

\section{Evaluation of Fertility of Treated Guinea Pigs}

After sacrifice, the following measurements were registered: number of pregnant cavies, number and weight of fetuses. These characteristics were used to evaluate the rates of fertility, viability and mortality indices.

\section{Biochemical Analysis}

- Hormonal assay
Serum content in reproductive hormones (FSH, LH and progesterone) were determined using appropriate commercial kits (ELISA AccuDiagTM, Diagnostic Automation Inc).

- Toxicity markers

The levels of total proteins, creatinine, urea, total cholesterol, AST and ALT in the serum were determined using CHRONOLAB kit following the manufacturer's protocol.

- Antioxidant markers

Superoxide dismutase (SOD), total peroxidase, Catalase activity and Malondialdehyde (MDA) were measured using the spectrophotometer (GENESYS 20.0) and according to the methods described respectively by (Nilsson et al., 1989; Misra and Fridovich, 1972; Sinha, 1972; Habbu et al., 2008).

\section{Evaluation of Reproductive Organs Weight}

After dissection, the female's gravid uterus, empty uterus and ovaries were collected and washed with normal saline to separate the surrounding fat and connective tissues. After drying, the weight was recorded with the aid of an electronic scale of $160 \mathrm{~g}$ capacity and $10^{-3} \mathrm{~g}$ precision.

\section{Histology}

The ovaries of each female were fixed in Bouin's solution for one week, embedded in paraffin, cut at $5 \mu \mathrm{m}$ and stained with Harris haematoxylin and eosin. The tissue sections were observed under a light microscope (Leica DM 750, X10 and X 40) for morphology harmony and cellular integrity.

\section{Statistical Analysis}

Values were presented as Mean \pm SEM. ANOVA was performed, for comparison with post-hoc Duncan test to compare the level of significance between the controls and experimental groups. Probability values less than $0.05 \quad(\mathrm{p} \leq 0.05)$ was considered statistically significant. Statistical analyses were performed with SPSS for Windows software program 20.0

\section{Results}

\section{Feed Intake, Body Weight and Relative Weight of Reproductive Organs}

The final body weight, body weight gain and feed intake highly decreased in the negative control (T0-) group as compared to the neutral control (T0). However, the values of these characteristics increased in vitamin $\mathrm{C}$ and Spirulina platensis-treated group (Table 2). 


\section{Fertility, Sex Organ Weight and Embryo Characteristics}

The fertility rate, viability rate, ovary weight, the full and empty uterus weight, litter size and weight decreased significantly $(\mathrm{p}<0.05)$ in lead-treated females. However, the co-treatment of lead and HESP increased these parameters compared to the positive control $(\mathrm{T}+)$ animals (Table 3$)$.

\section{Reproductive Serum Hormones}

Lead acetate-treated group (T-) showed a nonsignificant $(p>0.05)$ decrease in serum level of LH and progesterone compared to the control (T0). HESP group showed a significant $(\mathrm{p}<0.05)$ increase in progesterone and a significant decrease in FSH and LH compared to T0 but similar to those of the positive control $(\mathrm{T}+)$ group (Table 4$)$.

Table 2: Effects of HESP on body weight, body weight gain and feed intake in females Guinea pig treated with lead acetate

\begin{tabular}{|c|c|c|c|c|c|c|c|}
\hline \multirow[b]{2}{*}{ Parameters } & \multicolumn{3}{|l|}{ Controls } & \multicolumn{3}{|c|}{ Doses of Spirulina(mg/kg.bw) } & \multirow[b]{2}{*}{$\mathrm{p}$} \\
\hline & $0(\mathrm{~T} 0)(\mathrm{n}=6)$ & Lead $(T-)(n=6)$ & Vit $\mathrm{C}(\mathrm{T}+)(\mathrm{n}=6)$ & $50(\mathrm{~T} 1)(\mathrm{n}=6)$ & $100(\mathrm{~T} 2)(\mathrm{n}=6)$ & $200(3)(n=6)$ & \\
\hline Initial body & $333.71 \pm 30.64$ & $330,21 \pm 72.71$ & $331.87 \pm 53.99$ & $353.28 \pm 59.35$ & $325.12 \pm 68.7$ & $338,12 \pm 68.88$ & 0.30 \\
\hline Final body & $524,00 \pm 79.64$ & $476.33 \pm 125.20$ & $489.66 \pm 68.6$ & $487.80 \pm 103.71$ & $516.11 \pm 121.17$ & $479.83 \pm 45.22$ & 0.81 \\
\hline Body gain & $191.11 \pm 23.67$ & $146,00 \pm 61.02$ & $158.79 \pm 89.63$ & $134.52 \pm 51.70$ & $191.12 \pm 68.06$ & $141.33 \pm 52.12$ & 0.07 \\
\hline Feed intake & $18294.45 \pm 70.20$ & $18187.83 \pm 13.09$ & $17264.67 \pm 13.15$ & $17303.85 \pm 11.65$ & $17778.77 \pm 13.21$ & $18357.98 \pm 20.32$ & 0.17 \\
\hline
\end{tabular}

n: number of animals, T0: neutral control; T-: negative control $12 \mathrm{mg}$ lead acetate/kg bw; T+: positive control lead acetate $12 \mathrm{mg} / \mathrm{kg}$ bw and $100 \mathrm{mg}$ vitamine C; T1: lead+HESP $50 \mathrm{mg} / \mathrm{kg}$ bw; T2: lead+HESP $100 \mathrm{mg} / \mathrm{kg}$ b.w. T3: lead+HESP $200 \mathrm{mg} / \mathrm{kg}$ bw; HESP: hydroethanolic extract of Spirulina platensis; $\mathrm{P}=$ probability value

Table 3: Effect of HESP on fertility, sex organ weight and fetus indices in female Guinea pig treated with lead acetate

\begin{tabular}{|c|c|c|c|c|c|c|c|}
\hline \multirow{2}{*}{$\begin{array}{l}\text { Characteristics } \\
\text { of reproduction }\end{array}$} & \multicolumn{3}{|l|}{ Controls } & \multicolumn{4}{|c|}{ Doses of spirulina (mg/kg.bw) } \\
\hline & $0(\mathrm{~T} 0)(\mathrm{n}=6)$ & $\mathrm{Pb}(\mathrm{T}-)(\mathrm{n}=6)$ & $\operatorname{VitC}(\mathrm{T}+)(\mathrm{n}=6)$ & $50(\mathrm{~T} 1)(\mathrm{n}=6)$ & $100(\mathrm{~T} 2)(\mathrm{n}=6)$ & $200(T 3)(n=6)$ & $\mathrm{p}$ \\
\hline Fertility index (\%) & $75.00 \pm 46.29^{\mathrm{a}}$ & $42.85 \pm 53.40^{\mathrm{b}}$ & $57.14 \pm 22.8^{\mathrm{ab}}$ & $71.42 \pm 48.79^{\mathrm{a}}$ & $62.5 \pm 51.7^{\mathrm{ab}}$ & $37.5 \pm 51.75^{\mathrm{b}}$ & 0.02 \\
\hline No. of fetuses/dam & $1.66 \pm 0.57$ & $1.33 \pm 0.57$ & $1.50 \pm 0.54$ & $1.40 \pm 0.54$ & $1.8 \pm 0.83$ & $1.33 \pm 0.57$ & 0.37 \\
\hline Viability index (\%) & $100.00 \pm 0,00$ & $80.12 \pm 57.04$ & $100.00 \pm 0,00$ & $100.00 \pm 0,00$ & $88.88 \pm 49.8$ & $100.00 \pm 0,00$ & 0.61 \\
\hline $\begin{array}{l}\text { Gravid uterine } \\
\text { weight }(\mathrm{g})\end{array}$ & $30.39 \pm 29^{\mathrm{ab}}$ & $33.66 \pm 42^{\mathrm{ab}}$ & $29.94 \pm 37.29^{b}$ & $56.56 \pm 65.11^{\mathrm{a}}$ & $66.8 \pm 67.16^{\mathrm{a}}$ & $29.71 \pm 3.20^{\mathrm{b}}$ & 0.03 \\
\hline $\begin{array}{l}\text { Empty uterine } \\
\text { weight }(\mathrm{g})\end{array}$ & $3.62 \pm 3.43$ & $3.14 \pm 1.92$ & $2.50 \pm 2.60$ & $4.50 \pm 3.93$ & $6.19 \pm 3.77$ & $4.59 \pm 1.86$ & 0.16 \\
\hline Ovaries weight & $0.066 \pm 0.02$ & $0.046 \pm 0.00$ & $0.07 \pm 0.01$ & $0.06 \pm 0.01$ & $0.06 \pm 0.01$ & $0.053 \pm 0.02$ & 0.16 \\
\hline Fetal weight (g) & $24.82 \pm 15.70^{\mathrm{b}}$ & $23.66 \pm 21.90^{\mathrm{b}}$ & $33.33 \pm 11.67^{\mathrm{b}}$ & $51 \pm 45.21^{\mathrm{ab}}$ & $66.4 \pm 44.86^{\mathrm{a}}$ & $22.33 \pm 9.0 \mathrm{à}^{\mathrm{b}}$ & 0.01 \\
\hline mortality index $(\%)$ & $0.00 \pm 0,00$ & $19.87 \pm 3.66$ & $0.00 \pm 0,00$ & $0.00 \pm 0,00$ & $11.11 \pm 4.09$ & $0.00 \pm 0,00$ & 0.15 \\
\hline
\end{tabular}

number of animal,. T0 : control; T- :negative control $12 \mathrm{mg}$ lead acetate/kg b.w; T0+: positive control $12 \mathrm{mg}$ lead acetate $/ \mathrm{kg}$ b.w with 100mg of vitamine $\mathrm{C}$; T1: lead+50 $\mathrm{mgHESP} / \mathrm{kg}$ b.w; T2: lead+100 mg HESP/kg b.w. T3: lead+200 mg HESP/kg b.w. HESP: hydroethanolic 1 extract of Spirulina platensis; $\mathrm{P}=$ probability value

Table 4: Effects of HESP extract on serum level of progesterone, luteinizing hormone and follicle stimulating hormone in female Guinea pig treated with lead acetate

\begin{tabular}{|c|c|c|c|c|c|c|c|}
\hline \multirow[b]{2}{*}{ Serum hormones } & \multicolumn{3}{|l|}{ Controls } & \multicolumn{4}{|c|}{ Doses of Spirulina platensis (mg/kg.bw) } \\
\hline & $0(\mathrm{~T} 0)(\mathrm{n}=6)$ & Lead(T-) $(n=6)$ & Vit $C(T+)(n=6)$ & $50(\mathrm{~T} 1)(\mathrm{n}=6)$ & $100(T 2)(n=6)$ & $200(T 3)(n=6)$ & $\mathrm{p}$ \\
\hline $\mathrm{FSH}(\mu \mathrm{M} / \mathrm{min} / \mathrm{g})$ & $34.06 \pm 7.80^{\mathrm{b}}$ & $35.70 \pm 7.19^{\mathrm{a}}$ & $35.18 \pm 4.18^{\mathrm{a}}$ & $34.21 \pm 6.47^{b}$ & $29.47 \pm 3.97^{\mathrm{b}}$ & $35.17 \pm 4.95^{\mathrm{a}}$ & 0.07 \\
\hline $\mathrm{LH}(\mu \mathrm{M} / \mathrm{min} / \mathrm{g})$ & $81.50 \pm 17.31^{\mathrm{a}}$ & $75.00 \pm 18.10^{\mathrm{a}}$ & $30.00 \pm 8.86^{\mathrm{b}}$ & $63.41 \pm 12.91^{\mathrm{ab}}$ & $30.50 \pm 9.38^{\mathrm{a}}$ & $74.25 \pm 6.74^{\mathrm{b}}$ & 0.02 \\
\hline Progesteron $(\mu \mathrm{M})$ & $28.15 \pm 8.61^{\mathrm{a}}$ & $15.56 \pm 8.38^{b}$ & $17.86 \pm 9.69^{\mathrm{ab}}$ & $14.15 \pm 2.90^{\mathrm{b}}$ & $22.03 \pm 4.40^{\mathrm{ab}}$ & $16.77 \pm 10.69^{\mathrm{b}}$ & 0.03 \\
\hline
\end{tabular}

n:number of animals, T0: neutral control; T-: negative control $12 \mathrm{mg}$ lead acetate/kg bw; T+: positive control lead acetate $12 \mathrm{mg} / \mathrm{kg}$ bw and $100 \mathrm{mg}$ vitamine C; T1: lead+HESP $50 \mathrm{mg} / \mathrm{kg}$ bw; T2: lead+HESP $100 \mathrm{mg} / \mathrm{kg}$ b.w. T3: lead+HESP $200 \mathrm{mg} / \mathrm{kg}$ bw; HESP: hydroethanolic extract of Spirulina platensis; FSH: folliculo-stimulating hormone, LH: luteinizing hormone 
Table 5: Effects of different levels of HESP on oxidative stress biomarkers in female Guinea pig treated with lead acetate Controls Doses of spirulina (mg/kg.bw)

\begin{tabular}{llllllll} 
Parameters & $0(\mathrm{~T} 0)(\mathrm{n}=6)$ & Lead(T-) $(\mathrm{n}=6)$ & Vit C (T+) $(\mathrm{n}=6)$ & $50(\mathrm{~T} 1)(\mathrm{n}=6)$ & $100(\mathrm{~T} 2)(\mathrm{n}=6)$ & $200(\mathrm{~T} 3)(\mathrm{n}=6)$ & $\mathrm{p}$ \\
\hline SOD $(\mu \mathrm{M} / \mathrm{min} / \mathrm{g})$ & $5.49 \pm 1.46^{\mathrm{a}}$ & $3.71 \pm 1.62^{\mathrm{b}}$ & $6.87 \pm 1.9^{\mathrm{ab}}$ & $4.87 \pm 2.12^{\mathrm{b}}$ & $5.10 \pm 2.26^{\mathrm{ab}}$ & $6.68 \pm 0.91^{\mathrm{ab}}$ & 0.02 \\
CAT $(\mu \mathrm{M} / \mathrm{min} / \mathrm{g})$ & $16.51 \pm 3.20^{\mathrm{a}}$ & $12.77 \pm 2.89^{\mathrm{b}}$ & $14.37 \pm 2.39^{\mathrm{ab}}$ & $17.73 \pm 1.59^{\mathrm{a}}$ & $16.58 \pm 5.75^{\mathrm{a}}$ & $15.39 \pm 5.47^{\mathrm{ab}}$ & 0.05 \\
MDA $(\mu \mathrm{M})$ & $0.36 \pm 0.00^{\mathrm{b}}$ & $0.58 \pm 0.18^{\mathrm{a}}$ & $0.44 \pm 0.16^{\mathrm{ab}}$ & $0.37 \pm 0.03^{\mathrm{b}}$ & $0.45 \pm 0.15^{\mathrm{ab}}$ & $0.28 \pm 0.03^{\mathrm{b}}$ & 0.00 \\
POD $(\mu \mathrm{M} / \mathrm{min} / \mathrm{g})$ & $36.84 \pm 19.54^{\mathrm{b}}$ & $21.15 \pm 11.26^{\mathrm{c}}$ & $49.21 \pm 21^{\mathrm{ab}}$ & $61.74 \pm 12.62^{\mathrm{a}}$ & $63.42 \pm 29.36^{\mathrm{a}}$ & $43.48 \pm 11.95^{\mathrm{ab}}$ & 0.00 \\
\hline
\end{tabular}

n:number of animals,. Means values for each parameter in the same row, with different superscripts (a,b) differ significantly (p $\leq$ 0.05). T0: neutral control; T-: negative control $12 \mathrm{mg}$ lead acetate/kg bw; T+: positive control lead acetate $12 \mathrm{mg} / \mathrm{kg}$ bw and $100 \mathrm{mg}$ vitamin C; T1: lead+HESP $50 \mathrm{mg} / \mathrm{kg}$ bw; T2: lead+ HESP $100 \mathrm{mg} / \mathrm{kg}$ b.w. T3: lead+HESP $200 \mathrm{mg} / \mathrm{kg}$ bw; HESP: hydroethanolic extract of Spirulina platensis, SOD: superoxyde dismutase; CAT: catalase; MDA: Malondialdehyde; POD: peroxidase; $\mathrm{P}=$ probability value

Table 6: Effects of different levels of HESP on toxicity biomarkers in female Guinea pig treated with lead acetate

\begin{tabular}{|c|c|c|c|c|c|c|c|}
\hline \multirow[b]{2}{*}{ Parameters } & \multicolumn{3}{|l|}{ Controls } & \multicolumn{4}{|c|}{ Doses of spirulina (mg/kg.pc) } \\
\hline & $0(\mathrm{~T} 0)(\mathrm{n}=6)$ & $\operatorname{Lead}(T-)(n=6)$ & $\operatorname{VitC}(\mathrm{T}+)(\mathrm{n}=6)$ & $50(\mathrm{~T} 1)(\mathrm{n}=6)$ & $100(\mathrm{~T} 2)(\mathrm{n}=6)$ & $200(T 3)(n=6)$ & $\mathrm{p}$ \\
\hline$\overline{\mathrm{AST}}(\mathrm{UI} / \mathrm{L})$ & $63.54 \pm 6.33^{\mathrm{b}}$ & $159.54 \pm 28.9^{\mathrm{a}}$ & $121.25 \pm 9.20^{\mathrm{ab}}$ & $122.90 \pm 10.3^{\mathrm{ab}}$ & $116.95 \pm 9.90^{\mathrm{ab}}$ & $114.2 \pm 10.7^{\mathrm{ab}}$ & 0.02 \\
\hline ALT (UI/L) & $68.68 \pm 4.71^{\mathrm{b}}$ & $119.93 \pm 7.23^{\mathrm{a}}$ & $80.25 \pm 5.74^{\mathrm{b}}$ & $86.78 \pm 3.70^{\mathrm{b}}$ & $100.50 \pm 5.10^{\mathrm{ab}}$ & $90.12 \pm 8.02^{\mathrm{ab}}$ & 0.17 \\
\hline Creatinine $(\mathrm{mg} / \mathrm{dl})$ & $0.44 \pm 0.15^{\mathrm{b}}$ & $1.20 \pm 0.36^{\mathrm{a}}$ & $0.77 \pm 0.38^{\mathrm{ab}}$ & $1.31 \pm 0.63^{\mathrm{a}}$ & $0.80 \pm 0.22^{\mathrm{ab}}$ & $0.70 \pm 0.60^{\mathrm{ab}}$ & 0.00 \\
\hline $\operatorname{Urea}(\mathrm{mg} / \mathrm{dl})$ & $35.11 \pm 1.10^{\mathrm{b}}$ & $51.74 \pm 8.85^{\mathrm{a}}$ & $46.20 \pm 8.50^{\mathrm{ab}}$ & $46.19 \pm 7.98^{\mathrm{ab}}$ & $44.60 \pm 8.76^{\mathrm{ab}}$ & $45.69 \pm 7.33^{\mathrm{ab}}$ & 0.03 \\
\hline Total proteins $(\mathrm{mg} / \mathrm{dl})$ & $3.42 \pm 0.73^{\mathrm{cd}}$ & $3.25 \pm 1.00^{\mathrm{d}}$ & $5.25 \pm 1.02^{\mathrm{ab}}$ & $4.01 \pm 0.78^{\mathrm{bcd}}$ & $4.83 \pm 0.79^{\mathrm{abc}}$ & $6.06 \pm 0.93^{\mathrm{a}}$ & 0.01 \\
\hline Total cholesterol $(\mathrm{mg} / \mathrm{dl})$ & $29.90 \pm 6.87^{\mathrm{a}}$ & $6.09 \pm 1.49^{\mathrm{b}}$ & $24.16 \pm 6.90^{\mathrm{a}}$ & $31.85 \pm 4.95^{\mathrm{a}}$ & $19.34 \pm 5.42^{\mathrm{ab}}$ & $30.70 \pm 9.26^{\mathrm{a}}$ & 0.03 \\
\hline
\end{tabular}

$\mathrm{n}$ :number of animals, each value represents mean \pm standard error mean. Means values for each parameter in the same row, with different superscripts $(\mathrm{a}, \mathrm{b})$ differ significantly $(\mathrm{p} \leq 0.05)$. T0: neutral control; $\mathrm{T}-$ : negative control $12 \mathrm{mg}$ lead acetate $/ \mathrm{kg}$ bw; $\mathrm{T}+$ : positive control lead acetate $12 \mathrm{mg} / \mathrm{kg}$ bw and $100 \mathrm{mg}$ vitamine C; T1: lead+HESP $50 \mathrm{mg} / \mathrm{kg}$ bw; T2: lead+HESP $100 \mathrm{mg} / \mathrm{kg}$ b.w. T3: lead+HESP $200 \mathrm{mg} / \mathrm{kg}$ bw; HESP: hydroethanolic extract of Spirulina platensis, AST: aspartate aminotransferase ALT: alanine aminotransferase; $\mathrm{P}=$ probability value

\section{Oxidative Stress Biomarkers}

The serum concentration of MDA significantly $(p<0.05)$ increased, whereas SOD, CAT and total peroxidases activities reduced significantly $(p<0.05)$ in the negative control compared to T0 group. The reverse trend was observed in HESP-treated groups (Table 5). Yet, the mean values of oxidative stress indicators in the HESP-treated groups were not significantly $(p>0.05)$ different from positive control ( $\mathrm{T} 0+$ ).

\section{Toxicity Biomarkers}

The serum levels of ALT, AST, creatinine and urea significantly $(\mathrm{p}<0.05)$ increased in stressed $(\mathrm{T}-)$ cavies as compare to the control (T0). The contrary was recorded with serum total protein and cholesterol (Table 6). Administration of HESP significantly $(p<0.05)$ decreased the serum levels of ALT AST, creatinine, urea and increased total proteins and cholesterol. The results recorded in vitamin $\mathrm{C}$ treated animals were similar.

\section{Histological Finding in the Ovaries}

The histopathological examination of ovaries of $\mathrm{T} 0$, showed a normal tissue and ovocyts, ovaries structure of stressed non-treated Guinea pigs exhibited evident signs of tissular injury such as atrophy and degeneration of the follicular cell and loss of vacuolars in the stroma with reduced presence of oocytes. HESPtreated animals (Fig. 2) showed improvement in ovary tissue structure and increased follicular cells compared to untreated animals and similar to vitamin $\mathrm{C}$ group.

\section{Discussion}

Exposure of animals to heavy metals is detrimental to their reproductive potential (Carocci et al., 2016; Dorea and Donangelo, 2006). Results of this study showed that there was a decrease in feed consumption, body weight and body weight gain in females Guinea pigs treated only with lead acetate compared to the control group which received distilled water and those co-exposed to lead acetate and hydroethanolic extract of Spirulina platensis. The reduction due to lead acetate can be explained by the fact that lead acetate could have had an inhibitory effect on the central nervous system which control feed intake (Madiha et al., 2008). The increase in these parameters with the administration of Spirulina platensis can be explained by the stimulation of the hypothalamus which might have provoked an increase in appetite and therefore in feed intake and body weight (Fox, 1999). Also, lead might have affected numerous other physiological functions including the female reproductive function (Flora et al., 2012). 

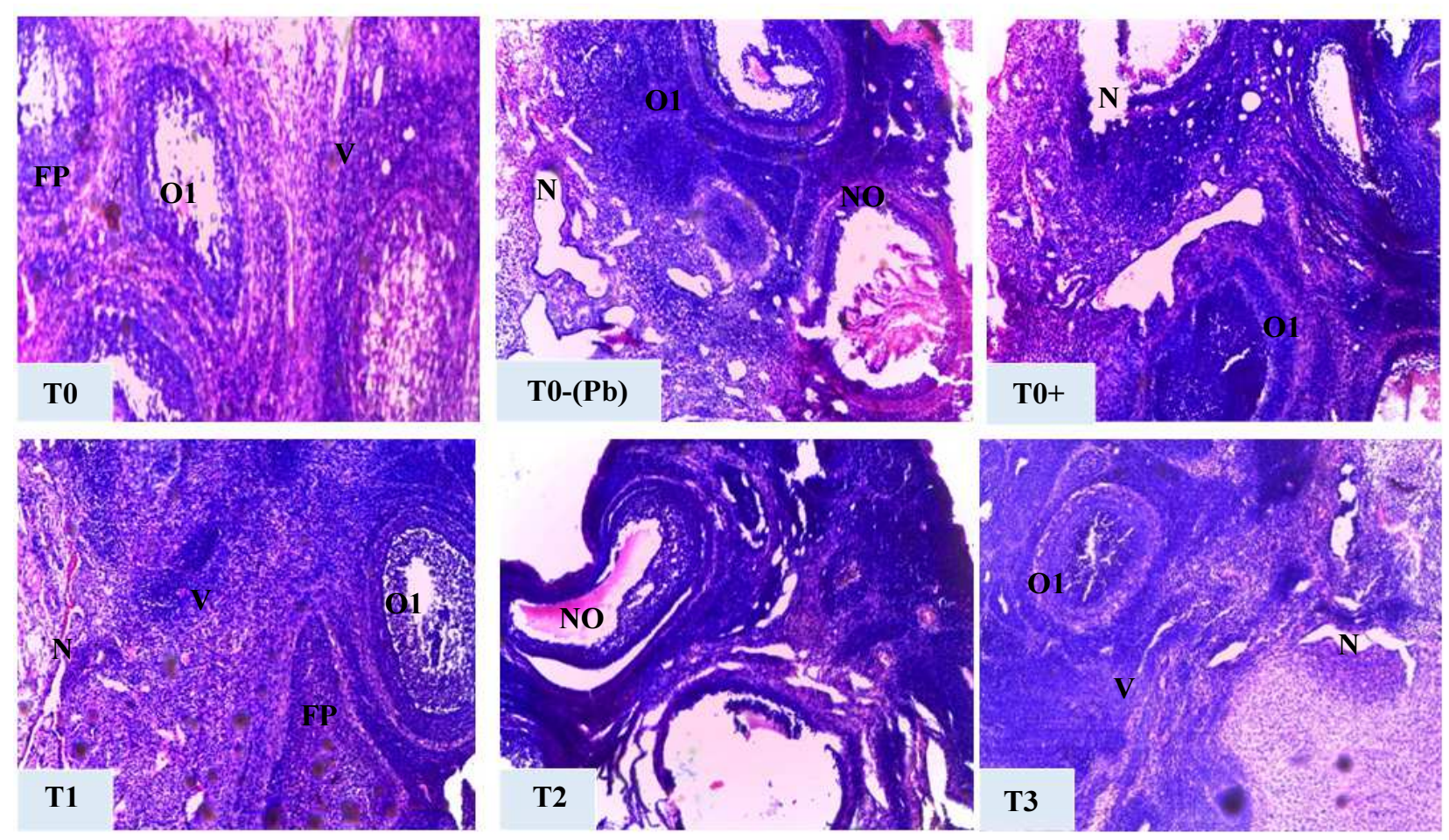

Fig. 1: Histology of ovary: T0: control; T-: Negative control: $12 \mathrm{mg}$ lead acetate $/ \mathrm{kg}$ b.w; T+: poitive control $12 \mathrm{mg}$ lead acetate/kg b.w with 100mg of vitamin C; T1: Lead+50 mg HESP/kg b.w; T2:* lead+100 mg HESP/kg b.w. T3: Lead+200 mg HESP/kg b.w. HESP: Ethanolic extract of Spirulina platensis O1: Primary ovocyte; FP: Primairy follicule; NO: Necrosis ovocyte; V: Vascularisation; N: Nécrosis

The current study also revealed that lead acetate caused a decrease of fertility rate, fetal weight and viability, ovaries and uterus weight in lead exposed female cavies. Administration of HESP led to higher fertility indices, weight of foetuses and consequently increase in uterus weight. This increase can be due to the presence of antioxidants in Spirulina (Khan et al., 2005). Antioxidants are known to have the capacity of stabilizing or deactivating free radicals before they attack cells and are also absolutely able of maintain normal cellular conditions and well-being (Gertrude, 2008). Lead acetate also induced female reproductive toxicity by disrupting endocrine and many other biochemical mechanisms (Abdou and Newairy, 2006). This study indicated that the serum concentrations of LH and progesterone decreased in lead acetate treated female cavies as compared to control. These results agree with those of Dearth et al. (2002) who reported that prepubertal females exposed maternally to low levels of lead exhibited suppressed circulating levels of estradiol. In addition, Franks and Laughlin (1989) and Foster et al. (1996) reported that exposure to lead decreases the plasma progesterone concentration. Many epidemiological studies also found that reproductive impairments may develop in females even with low-tomoderate blood lead level, including intrauterine growth restriction, preterm delivery (Srivastava et al., 2001) and spontaneous abortion. (Tang et al., 2003). The present results support the hypothesis that the action of lead on female's fertility may be due in part to the down-regulation of progesterone, LH and estradiol (the main female sex hormones) by activating their metabolizing enzymes. Therapy treatment of lead-stressed female Guinea pigs with Spirulina platensis attenuated the hormones disruption by increasing their levels. The correction of hormones damage in female Guinea pigs treated with HESP can be due to the phytosterols, saponins, polyphenols and flavonoids present in the extract. Many studies have shown that these compounds increase the level of reproductive hormones (Estrada et al., 2001; Khan et al., 2005).

The hepatocellular enzymes (AST, ALT) and the levels of creatinine, urea, total proteins and cholesterol are used to evaluate the function of the liver and kidney. The decrease in their activities in the liver and the kidney could be expected to occur associating with the pathology involving necrosis of theses organs. Rahman et al. (2001) suggested that the decrease in these parameters might show the stressed conditions of the treated animals. The present study indicated a decrease in the total proteins and cholesterol which could be attributed in part to the damaging effect of lead acetate on liver and kidney cells as confirmed by the increase in the activities of serum AST, ALT, creatinine and urea. However, administration of HESP 
restored theses parameters towards normal which may be due to its anti-oxidative and hepato-protective activities that scavenged the reactive oxygen species due its content. Spirulina is an important herbal medicine that has antioxidant properties and scavengers of oxidative stress (Mazo et al., 2004; Iyyapu et al., 2006). A significant increase in Malondiadehyde level was observed in female cavies exposed to lead acetate in the present study. These results are in line with the observations of Adibmoradi et al. (2015) after lead acetate administration. The significant increase in MDA level suggests that oxidative stress is a major mechanism of the effect of lead in organism. However, MDA level decreased significantly in a dose dependent manner in HESP-treated. Therefore, it can be concluded that HESP plays a protective role through its antioxidant activity. The decrease in MDA concentration might be linked to the increase of antioxidants production in the HESP-treated groups. The activities of SOD, CAT and POD in the tissue decreased in females exposed to lead acetate treatment cavies, nevertheless, restoration in spirulina-treated females suggested that spirulina has protective effects against oxidative stress induced by lead acetate (Khan et al., 2005). Therefore, it can be concluded that HESP plays a curative role through its antioxidant activity.

Histological analysis can also be used to examine the morphological changes in ovary to reflect possible effect of lead on the ovaries cells and reproductive hormones. Analysis of the micrographs revealed gross structural disintegration in the cortex when compared with the control. This disintegration is evidenced by the presence of large opened spaces. Loekle et al. (1983) described these open spaces as areas of tissues disintegration. The micrographs of HESP cavies showed minimal alterations with reduced fat deposition as compared to the lead acetatetreated cavies. These findings confirmed the curative effect of Spirulina platensis against the histological changes in lead acetate and its ability to improve the functional efficiency of the uterus and ovary.

\section{Conclusion}

The hydroethanolic extract of Spirulina platensis minimizes the adverse effects of lead-induced reproductive stress in adult female's Guinea pigs due to its antioxidant properties. Thus, the hydroethanolic extract of Spirulina platensis as well as vitamin C could be used as curative alternative to alleviate the effects of reproductive stress induced by lead acetate in female reproductive system.

\section{Funding Statement}

This research did not receive any specific grant from funding agencies in the public, commercial, or not-forprofit sectors.

\section{Author's Contributions}

Ngoula Ferdinand and Tchoumboue: Supervised and designed the project, cross checked the draft of the manuscript and finally approved for submission.

Deutcheu Nienga Sorelle and Ngoula Ferdinand: Designed the project, conducted the experiment, collected, analyzed data and wrote the first draft of the manuscript.

Mabou Nguemo Jasmine Laura, Manfo Tsague F. Pascal: Assisted in the conduction of the experiment, collected data.

Vemo Bertin Narcisse and Ngoumtsop Victor Herman: Conducted laboratory analysis of experiment. Ngouateu Kenfack Omer Bébé and Manfo Pascal: Rechecked the draft of the manuscript.

\section{Conflict of Interests}

The authors declare that they have no financial or personal conflict which may have inappropriately influenced them in writing this article.

\section{Ethical Consideration}

Experimental protocols used in this study were approved by the Ethical Committee of the Department of Animal Science of the University of Dschang-Cameroon (ECDAS-UDs 26/07/2017/UDs/FASA/DSAES) and was in conformity with the internationally accepted standard ethical guidelines for laboratory animal use and care as described in the European Community guidelines; EEC Directive 86/609/EEC, of the 24th November 1986.

\section{References}

Abdou, H.M. and A.A. Newairy, 2006. Hepatic and reproductive toxicity of lead in female rats and attenuation by flaxseed lignans. J. Medi. Res. Institute JMRI, 4: 295-302.

Adibmoradi, M., H. Morovvati, H.R. Moradi, M.T. Sheybani and J.S. Amoli, 2015. Protective effects of wheat sprout on testicular toxicity in male rats exposed to lead. Reproductive Sys. Sex Disord, 4: 156. DOI: 10.4172/2161-038X.1000156

Carocci, A., A. Catalano, G. Lauria, M.S. Sinicropi and G. Genchi, 2016. Lead toxicity, antioxidant defense and environment. Rev. Environ. Contam Toxicol., 238: 45-67.

Cruchot, H., 2008. La spiruline, bilan et perspective. Thèse docteur en pharmacie. Université de France-Comite.

Dearth, R.K., J.K. Hiney, V.K. Srivastava, S.B. Burdick and G.R. Bratton et al., 2002. Effects of lead $(\mathrm{Pb})$ exposure during gestation and lactation on female pubertal development. Reproductive Toxicol., 16: 343-52. 
Dorea, J.G. and C.M. Donangelo, 2006. Early (in uterus and infant) exposure to mercury and lead. Clinical Nutrut. 25: 369-76.

Estrada, J.E., P.B. Bermejo and D.F.A.M. Villar, 2001. Antioxidant activity of different fractions of Spirulina platensis protean extract. Phyto. Chem., 61: 12-16.

Flora, G., D. Gupta and A. Tiwari, 2012. Toxicity of lead: A review with recent updates. Interdiscipline Toxicol.. 5: 47-58.

Foster, W.G., A. Memahon and D.C. Rice, 1996. Subclinical changes in luteal function in cynomolgus monkeys with moderate blood lead levels. J. Apply Toxicol., 16: 159-63.

Fox, S.I., 1999. Human Physiology, $6^{\text {th }}$ Edn., Boston: Mc. Graw-Hill.

Franks, P.A. and N.K. Laughlin, 1989. Effects of lead on luteal function in rhesus monkeys. Bio. Reproduct., 41: 1055-62.

Gertrude, L.A.D., 2008. Ethnobotany and ecological studies of plants used for reproductive health: A case study at biosphere reserve in the Western Region of Ghana. Young Scientists Research Final Report Submitted To the Division of Ecological Sciences UNESCO (MAB) Young Scientist Research Award Scheme Paris Cedex 15 France.

Habbu, P.V., R.A. Shastry, K.M. Mahadevan, J. Hanumanthachar and S.K. Das, 2008. Hepatoprotective and antioxidant effects of argyreia speciosa in rats. African J. Traditional Complementary Alternative Medi., 5: 158-164.

Halliwell, B. and J.M.C. Gutteridge, 2007. Free Radicals in Biology and Medicine. 4 Edn, Oxford University Press, Oxford, New York, ISBN-10: 9780198568681, pp: 851.

Hayashi, K., T. Hayashi and I. Kojima, 1996. A natural sulfated polysaccharide, calcium spirulin, isolated from Spirulina platensis: In vitro and ex vivo evaluation of anti-herpes simplex virus and antihuman immunodeficiency virus activities. AIDS Res. Human Retroviruses, 12: 1463-1471.

DOI: 10.1089 /aid.1996.12.1463

Iwata, K. and K.T. Inayama, 1987. Effects of Spirulina platensis on fructose induced hyperlipidemia in rats. J. Japan Soci. Nutrit. Food Sci.. 40: 463-467.

Iyyapu, K.M., K. Mahmood, C.S. Jagdish, U.R.N. Madireddy and K.K. Vijay et al., 2006. Protection against Cisplatin-induced nephrotoxicity by Spirulina in rats. Cancer Chem. Pharmacol., 58: 802-808. DOI: $10.1007 / \mathrm{s} 00280-006-0231-8$

Khan, Z., P. Bhadouria and P.S. Bisen, 2005. Nutritional and therapeutic potential of Spirulina. Curr. Pharm. Biotecnol., 6: 373-379.
Liu, L, B. Guo, J. Ruan, X. Dai and B. Wu et al., 1991. Study on effect and mechanism of polysacchrides of Spirulina platensis on body immune functions impovenment. Marine Sci., 6: 44-49.

Loekle, M.D., A.J. Schecter and J.J. Christian, 1983. Effects of chloroform, tetrachloroethylene and trichloroethylene on survival growth and liver of Poecillia sphenops. Bull. Environ. Contam. Toxicol., 30: 199-205.

Madiha, M., S. Heba, A.M. Dorreia and G. Nessrin, 2008. The effect of lead cetate on testicular structure on Adult albino Rats. Egypt. J. Histolol.. 31: 406-418.

Mazo, V.K., V.G. Moshinskii and I.S. Zilova, 2004. Microalgae. Spirulina Human Nutrit. Vopr. Pitan., 73: 45-53.

Misra, H.P. and I. Fridovich, 1972. The generation of superoxide radical during the autoxidation of hemoglobin. J. Bio. Chem., 247: 6960-6962.

Nilsson, U.A., L.I. Olsson, G. Carlin and A.C. BylundFellenius, 1989. Inhibition of lipid peroxidation by spin labels. J. Bio. Chem., 264: 11131-11135.

Patrick, L., 2006. Lead toxicity part II: The role of free radical damage and the use of antioxidants in the pathology and treatment of lead toxicity. Alternative Medi. Record., 11:114-27.

Qureshi, M.A., J.D. Garlich and M.T. Kidd, 1996. Dietary Spirulina platensis enhances humoral and cell mediated immune functions in chickens. Immunopharmacol. Immunotoxicol., 18: 465-476.

Rahman, M.F., M.K. Siddique and K. Jamil, 2001. Acid and alkaline phosphatase activities in a novel phosphorothionate (RPR-11) treated male and female rats. Evidence of dose and time-dependent response. Drug Chemical Toxicol., 32: 479-509. DOI: 10.1081/DCT-100100131

Raji, Y., O.O. Fadare, R.A. Adisa and S.A. Salami, 2006. Reprodut. Medi. Bio., 5: 283-292.

Saxena, R. and P. Garg, 2010. Vitamin E provides protection against in vitro oxidative stress due to pesticide (chlorpyrifos and) in goat RBC, Bull Biosci. Endosulfan, 1: 1-6.

Sinha, A.K., 1972. Colorimetric assay of catalase. Analytical Biochem., 47: 389-394.

Soheir, A.A., 2015. Effect of pumpkin oil and vitamin e on lead induced testicular toxicity in male rats. J. Anim. Plant Sci., 25: 72-77.

Srivastava, S., P.K. Mehrotra, S.P. Srivastava, I. Tandon and M.K. Siddaqur, 2001. Blood lead and zinc in pregnant women and their offspring in intrauterine growth retardation cases. J. Anim. Toxicol., 25: 461-5. 
Tang, S., R. Lauwerys and D. Lison, 2003. Adverse reproductive effects in female workers of lead battery plants. Int. J. Occupat. Med. Environm. Health, 16: 359-61.

Wu, L.C., J.A. Ho, M.C. Shieh and I.W. Lu, 2005. Antioxidant and antiproliferative activities of Spirulina and Chlorella water extracts. J. Agr. Food Chemical., 53: 4207-4212.
Yildirim, N.C., F. Benzer and D. Danabas, 2011. Evaluation of environmental pollution at Munzur river of Tunceli applying oxidative stress biomarkers in Cappota trutta (Heckel, 1843). J. Anim. Plant Sci., 21: 66-71. 